\title{
A Method and Device for 3D Recognition of Cutting Edge Micro Geometry
}

\section{Metoda i uređaj za 3D prikaz mikrogeometrije rezne oštrice}

Original scientific paper • Izvorni znanstveni rad

Received-prispjelo: 21. 12. 2012.

Accepted-prihvaćeno: 6. 2. 2014.

UDK: $630 * 822.02$

doi:10.5552/drind.2014.1255

\begin{abstract}
A$ very useful method was successfully applied in the investigation of tools for machining wood and wood based composites. It allows scanning of the cutting edge micro geometry in three dimensions and reproducing it in a virtual space as a 3D surface. The application of the method opens new possibilities of studying tool wear by scanning, including the calculation of volume loss and other analysis of tool wedge geometry along and perpendicularly to the cutting edge. Effectiveness of the method and scanner were successfully verified by a reference ESEM (Environmental Scanning Electron Microscopy) method.
\end{abstract}

Keywords: cutting tool wear, 3D scanner, micro geometry

SAŽETAK • Vrlo korisna metoda skeniranja uspješno je primijenjena za istraživanje alata za obradu drva $i$ kompozita na bazi drva. Metoda omogućuje skeniranje mikrogeometrije rezne oštrice u tri dimenzije i ponovni prikaz u virtualnom prostoru kao $3 D$ površina. Primjena metode otvara nove mogućnosti istraživanja trošenja alata skeniranjem, uključujući izračun volumena gubitka materijala trošenjem alata ili druge analize geometrije alata uzdužno ili okomito na reznu oštricu. Učinkovitost metode i skener uspješno su verificirani uz pomoć ESEM (Environmental Scanning Electron Microscopy) metode.

Ključne riječi: trošenje alata za rezanje, $3 D$ skener, mikrogeometrija

\footnotetext{
${ }^{1}$ Author is assistant professor at Department of Woodworking Machinery and Basis of Machines Construction, Poznan University of Life Sciences, Poznan, Poland. ${ }^{2}$ Author is PhD student at Faculty of Computer Science and Management, Poznan University of Technology, Poznan, Poland. ${ }^{3}$ Author is researcher at Trees and Timber Institute/National Research Council IVALSA/CNR, San Michele All'Adige, Italy. ${ }^{4}$ Author is assistant professor at Department of Material Sciences and Process Engineering, Institute of Physics and Materials Science, BOKU - University of Natural Resources and Life Sciences, Vienna, Austria. ${ }^{5}$ Author is professor at Department of Manufacturing Engineering and Automation, Faculty of Mechanical Engineering, Gdansk University of Technology, Gdansk, Poland, and also association with IVALSA/CNR Trees and Timber Institute, Italy.

${ }^{1}$ Autor je docent Odjela za strojeve za obradu drva i osnove konstrukcija strojeva, Sveučilište bioloških znanosti, Poznan, Poljska. ${ }^{2}$ Autor je doktorand Fakulteta računalnih znanosti i menadžmenta, Sveučilište tehnologije u Poznanu, Poznań, Poljska. ${ }^{3}$ Autor je istraživač Instituta za drveće i drvo / Nacionalni istraživački savjet IVALSA/CNR, San Michele All'Adige, Italija. ${ }^{4}$ Autor je docent Odjela za znanosti o materijalima i proizvodno inženjerstvo, Institut za fiziku i znanosti o materijalima, BOKU - Sveučilište prirodnih resursa i bioloških znanosti, Beč, Austrija. ${ }^{5}$ Autor je profesor Odjela za proizvodno inženjerstvo i automatizaciju, Fakultet strojarstva, Sveučilište tehnologije u Gdansku, Gdansk, Poljska te surađuje s Institutom za drveće i drvo IVALSA/CNR, Italija.
} 


\section{INTRODUCTION}

\section{UVOD}

The final quality of machining of wood and wood based composites (WBC) depends on many factors, which may be grouped into 4 categories: machined material (including its orientation), cutting conditions (cutting situation, cutting speed, feed speed, feed per tooth, uncut chip thickness, etc.), machine and tool. All these factors (including tool quality) have to be optimal in order to obtain satisfying surface and edges of a material. Construction of a standard rotary tool is based on a tool body supporting one or more cutting edges, regardless whether the tool is a compound assembly or the cutting edges are shaped directly from the tool's body. A tool's body has to be stiff enough to ensure proper positioning of cutting edges subjected to stresses, to be well balanced statically and dynamically, to have room for chips produced during cutting in order to remove them out of the cutting zone, to have no runout clamping system, etc. Supposing that the tool's body fulfills all these demands and the geometry of teeth is properly selected (e.g. clearance, rake, flank clearance angles), there is one more, very important, parameter influencing any kind of wood or WBC machining - micro geometry of tool tip - particularly its sharpness.

A sharp tool has a positive influence not only on machined surface geometry, but also on reducing cutting forces, decreasing energy consumption, minimizing vibrations and noise level. On the other hand, a worn tool - particularly in case of extreme wear - has a great impact on the surface quality and on machine dynamics (Paris and Peigne, 2007). Since sharp tools are highly desired by industrial tool users, it has been of highest interest to increase the life-span of tools (time of usage ensuring quality demands). It is crucial, therefore, to understand the process of tool blunting. This issue has already been studied by several researchers. Ramasamy and Ratnasingam (2010) for example, pointed out that tool wearing might be caused by: gross fracture or chipping (catastrophic) abrasion, erosion, micro fracture, electrochemical corrosion and oxidation. However, depending on the process, tool and machined materials, the rate of each can vary. In consequence, new, more wear-resistant cutting tool materials and/or coatings and bulk materials are introduced into tool production (Sheikh-Ahmad and Bailey, 1999). These include new generation tungsten carbides, Polycrystalline Diamond, Diamond Dispersed Cemented Carbides, and various PVD/CVD coatings, among others. The development requires, however, good techniques for recognizing the tool wear in order to verify the effectiveness of improvements.

It has been the interest of many researchers for years to recognize the tool wear during wood machining. Klamecki (1979) states that: "The change in the cutting tool with use has generally been monitored in two ways, by observing the change in the edge geometry, and by observing changes in the forces acting during cutting". He also notices that some authors have used other measures of tool dulling e.g. time needed to plane a given length of wood while applying a constant feed force, or the size of sawdust chips used as an indicator of tool wear. Even if the above statement was still valid, it should not be forgotten than the generated surface quality is probably the most important among all. It can be concluded that all methods of tool wear measurement may be divided into: direct and indirect.

\subsection{Direct methods \\ 1.1. Direktne metode}

The most obvious way of controlling the tool wear is a direct measurement of tool geometry. It has several disadvantages: time-consuming duration (disassembling, measuring and assembling a tool or a blade) and difficulties in assembling the tool (after measurement) in exactly the same position. This disqualifies direct methods as real time (or on-line) measurements. On the other hand, these provide objective and absolute wear results (Bonamini et al., 1999). Three techniques of direct tool tip geometry measurement are usually used: contact, optical and SEM.

Contact methods rely on scanning the cutting edge by means of tip or wedge type stylus moved along or perpendicularly to achieve tool wedge profile (Miklaszewski et al., 2000, Novacek and Novak, 2006). A 3D representation of a tooth can be obtained by repeating scanning profile by profile and by combining them together.

A non-destructive silicone cast cross-section method is another alternative for reproducing the cutting edge profile in the contacting mode (Miklaszewski et al., 2000; Sheikh-Ahmad and Bailey, 1999). It is, however, rarely used due to rather intensive preparation work of casts and significant time necessary for scrutinizing data.

Optical approach for scanning cutting edge geometry has several varieties. In the simplest setup, optical microscope is used to observe the tool tip. If the microscope is equipped with a camera, it is then possible to capture the image and afterwards to analyze by means of image processing methods (Aknouche et al., 2009; Kowaluk at al., 2009; Lemaster at al., 2000a; Nordström and Bergström, 2001). Putting Vickers indentation marks (or surface scratches) on the observed face as a spatial reference proved to be useful. The progress of the distance between the mark and the cutting edge might then be used as an indicator of wear rate (Bonamini et al., 1999; Ishida et al., 2005; McKenzie and Karpovich, 1975). Moreover the measurement does not depend on the initial edge wear as the measuring base is steady.

Kapcia et al. (2010) presented a mechatronic system for automatic inspection of circular saw teeth in an off-line manner. The described system has been implemented, based on numerical processing of recorded tooth images, in the automatic vision controller system WKOPTar. The system allows the user to determine up to 32 geometrical parameters for one tooth. However, the direct interpretation of physical parameters is sometimes partially limited by the software applied be- 
cause the same parameter might have different meaning (Wasielewski and Orlowski, 2005).

Methods using laser light are also considered optical methods. Some trials have been undertaken to acquire a measure of tool geometry in-situ on the rotating spindle: Ohuchi et al. (2003) have used laser curtain instrument for detecting outer diameter of a router bit. They successfully compared the results with a stylus method.

Several optical methods giving 3D surface models of a cutting edge zone have been previously considered by Sandak et al. (2011). Laser micrometric scanner, laser displacement sensor, laser line triangulation, shadow triangulation and depth-from-focus have been analyzed to verify their potentials.

Scanning Electron Microscope (SEM) is used to measure the tool wear. In many cases (Fuchs at al., 2005; Okai et al., 2006; Sheikh-Ahmad and Bailey, 1999) SEM is used in the same way as an optical microscope to make high resolution images, which are then subjected to geometry measures or simply qualitative analysis. Compared to optical microscopy, SEM has the great advantage of having a much higher depth of focus, which is favorable for $3 \mathrm{D}$ reconstruction by stereovision. Stereovision is at the moment one of the most precise methods of reproducing tool tip micro geometry into a 3 dimensional virtual space. SEM techniques have a great structural disadvantage though: limited chamber space that often leads to destroying the tool by breaking its teeth, making it unusable for further monitoring of tool wear.

Regardless of the measuring method, different parameters are used by authors to quantify tool wear.

McKenzie and Karpovich (1975) have used many parameters in order to provide a wide spectrum of tool blunting related to cutting forces. None of their parameters was linearly related to the cutting forces. Porankiewicz et al. (2005) noticed that, in wood cutting, edge recession on the clearance face $\left(\mathrm{VB}_{\mathrm{F}}\right)$ was the most intensive of all measured parameters in their experiment. This was confirmed by Sheikh-Ahmad and Bailey (1999) based on replica cross-section. SheikhAhmad et al. (2003) have used nose width - wear land measured in a surface perpendicular to the tool angle bisector. Alternatively, a cutting edge rounding (tool tip radius) might be used for the quantification of tool wear (Bonamini et al., 1999). Most wear measures proposed by authors are the result of the available two dimensional tooth edge profiles.

Recent developments in the area of 3D scanning of cutting edges have opened new possibilities of developing other tool wear indicators than those presented above. Some of 3D scanning methods have been already applied in metal cutting tools. Niranjan Prasad and Ramamoorthy (2001) have successfully used simplified stereometric imagining method to detect tool crater wear. Durazo-Cardenas et al. (2007) used TalySurf surface profilometer based on white light interferometry to obtain 3D representation of tool wear. This method is, however, intended for more or less flat surfaces and does not seem suitable for tool wedges.

\subsection{Indirect methods}

1.2. Indirektne metode

A number of indirect methods of tool wear recognition have been developed in parallel to direct measurement of cutting edges geometry, especially within on-line applications. From practical point of view, it is not the geometry of the tool that matters but the effect it makes on the process (quality of generated surface, energy consumption, sound intensity, etc). For this reason, as well as because of online possibilities, indirect measures of tool wear seem to be a very attractive alternative to adaptive control of cutting processes.

So far, besides cutting forces that were considered by many researchers (Aknouche et al., 2009, Klamecki, 1979), several other physical effects of cutting have also been researched in order to predict the tool wear. These include energy consumption, vibrations (Lemaster et al., 2000a, 2000b), acoustic emission (Lemaster and Tee, 1985; Tanaka et al., 1992), and temperature of machined surface (Sokolowski and Gogolewski, 1999). It should be emphasized though, that in most cases for the calibration of indirect measurement systems, series of data of the cutting tool micro geometry are required as a reference.

Therefore, the goal of this work was to develop, based on previous studies (Sandak et al., 2011), a dedicated methodology and device for virtually reproducing the cutting edge form and for providing information about its micro geometry in three dimensions. Another objective was to develop an algorithm for automatic determination of selected tool wear parameters.

\section{MATERIAL AND METHODS} 2. MATERIJAL I METODE

\subsection{Three dimensional reproduction of the cutting edge}

2.1. Trodimenzionalni prikaz rezne oštrice

The shadow line sectioning (triangulation) was chosen for the present study from many techniques mentioned above. It was previously found (Sandak et al. 2011) to be the most reliable of all tested methods of tooltip scanning. The method works as follows: a structured light-shadow border (light half plane) is projected on the scanned object at a specific angle and the image of this boundary is observed at the same time from another angle (Fig. 1).

The light-shadow border line represents the object contour. On the flat surface perpendicular to the camera's optical axis, the border appears as a horizontal line. When the surface is moved along this optical axis, the horizontal border line (between bright and dark half-planes) changes its vertical position at the image recorded by the camera. It gives information about the third dimension - depth. The lower the position of the image line (at the present setup), the farther it is located from the camera. If the pattern is projected onto a wedge (e.g. of the tool tip), the border line folds into a double slope hill (Fig. 1 and 3). In that case each 
a)

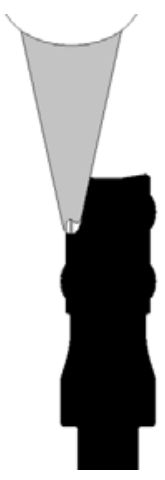

b)

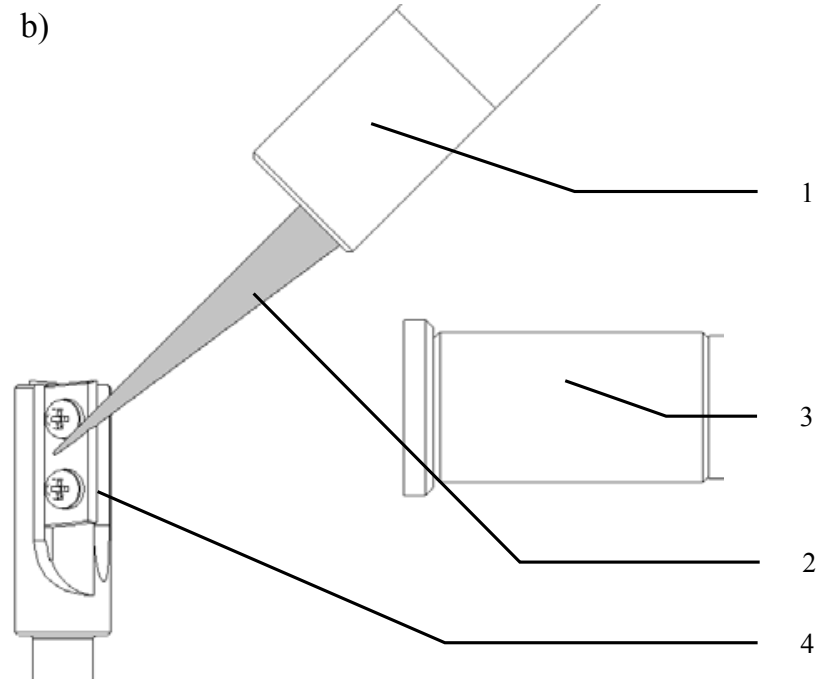

Figure 1 Shadow line sectioning (triangulation) technique: a) the camera point of view: light-shadow border projected on the tool illuminates tool tip (white) and discovers the shape of the cutting edge section b) side view of projector-camera-tool setup. 1) LED projector with lenses, 2) light beam, 3) camera with lenses, 4) inspected tool

Slika 1. Tehnika prikazivanja linije sjene (triangulacija): a) točka gledišta kamere - granica svjetlo - sjena projicirana na alat osvjetljava vrh alata (bijelo) i otkriva oblik presjeka rezne oštrice; b) bočni pogled na sustav projektor - kamera - alat: 1

- LED projektor s lećama, 2 - svjetlosna zraka, 3 - fotoaparat s lećama, 4 - alat

point of the border line may be located on a different depth and consequently the line is not straight anymore. Some more details regarding the principles of triangulation measurement as well as analysis of scanning error have been presented in the previous work of the authors (Sandak, 2007). An example of application of the light-shadow scanner has been presented in the work of Sandak et al. (2005).

\subsection{Scanner hardware and software}

\subsection{Hardver i softver skenera}

The scanner's hardware was designed and built based on the method and assumptions discussed above. The scanner was configured like a miniature 4 axis $\mathrm{CNC}$ machine having motorized three perpendicular axes $X, Y$ and $Z$ and one rotational $C$ axis allowing the rotation of tool around $Z$ axis (Fig. 2). An inspected tool (5) was fixed in a universal, self-centering chuck (3) mounted on rotary stage of $C$ axis (2). This set was then fixed on two-directional $X-Y$ moving table (1) with $100 \times 100 \mathrm{~mm}$ movement range. The core of the ToolScan system - an optical unit - was attached to the $Z$-axis linear table (4) placed vertically. The optical system included a camera (6) and projector (7). The camera was monochromatic CCD 2/3" with the resolution $2448 \times 2050$ pixels coupled with low distortion macro lenses. The source of light (3W LED red light projector) was equipped with the light-shadow pattern and telecentric lenses ensuring superior quality and simultaneously low distortion projection. The angle between optical axes of the projector and the camera was $45^{\circ}$. Both positioning and optical systems were put in a darkroom housing to avoid external light to interfere with the projected one. Selected functional parameters of the scanner are shown in Table 1.

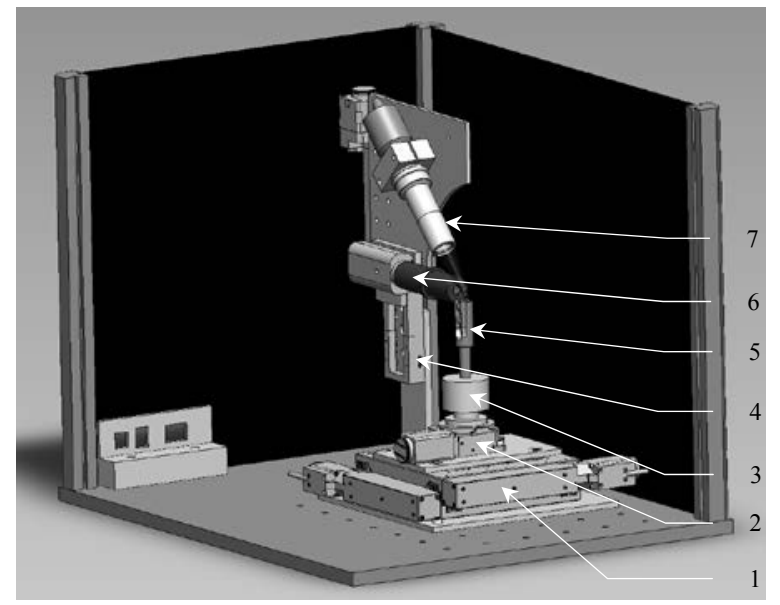

Figure 2 Design of ToolScan scanner: 1) $X Y$ moving stage, 2) rotary stage, 3) self-centering chuck, 4) $Z$ moving stage, 5) tool under inspection, 6) camera, 7) light projector Slika 2. Dizajn skenera ToolScan: $1-X Y$ pokretno postolje, 2 - rotirajuće postolje, 3 - samocentrirajuća stezna glava, 4 - postolje pokretno u smjeru osi $Z, 5$ - alat, 6 - kamera, 7 - svjetlosni projektor

The process of scanning is automatic; however before starting it, a few parameters have to be set up. First of all, the inspected cutting edge has to appear in the camera field of view and both clearance and rake faces should be visible. This is done with help of the manipulation panel. Then the exposition time has to be chosen, depending on reflective behavior of the teeth material. Diamond tipped tools need generally shorter exposition time than HM or HSS tools. Finally, the length of cutting edge to be scanned and the scanning resolution have to be defined. 
Table 1 Basic characteristics of positioning and optical systems

Tablica 1. Osnovna obilježja pozicioniranja i optičkog sustava

\begin{tabular}{|c|c|c|}
\hline & Range / Raspon & $\begin{array}{l}\text { Resolution } \\
\text { Rezolucija } \\
\end{array}$ \\
\hline$X$ axis & $100 \mathrm{~mm}$ & $0,3 \mu \mathrm{m}$ \\
\hline$Y$ axis & $100 \mathrm{~mm}$ & $0,3 \mu \mathrm{m}$ \\
\hline$Z$ axis & $100 \mathrm{~mm}$ & $0,125 \mu \mathrm{m}$ \\
\hline$C$ axis & $360^{\circ}$ & $4,5^{\prime \prime}$ \\
\hline $\begin{array}{l}\text { Camera field of } \\
\text { view - adjustable } \\
\text { Područje vidnog } \\
\text { polja kamere } \\
\text { - prilagodljivo }\end{array}$ & $\begin{array}{l}2,9 \times 2,2 \div \\
126 \times 102 \mathrm{~mm}\end{array}$ & $\begin{array}{l}1,2 \div 50 \\
\mu \mathrm{m}\end{array}$ \\
\hline
\end{tabular}

In the present configuration, 3D scanning requires a set of images to reproduce the map of the tooth tip surface in a virtual space. For this reason, the camera and the tool have to move along the cutting edge. While moving, the camera is triggered by the encoder with the frequency depending on the movement speed and selected resolution. As a result of scanning, the set of images is acquired and subjected to further analysis.

The calculation algorithm is divided into three main tasks, executed sequentially:

- analysis of the single image providing the profile of the tool

- conversion of the two-dimensional (2D) coordinates into the three-dimensional (3D) space and calculation of the angles required for proper aligning of the tool in 3D space

- calculation (in 3D space) of the missing points of the surface model, based on modified Shepard algorithm and final image post-processing

Analysis of the single image acquired from the scanner (Fig. 3a) is the most important stage of the whole image processing algorithm due to its impact on further processing steps.

a)

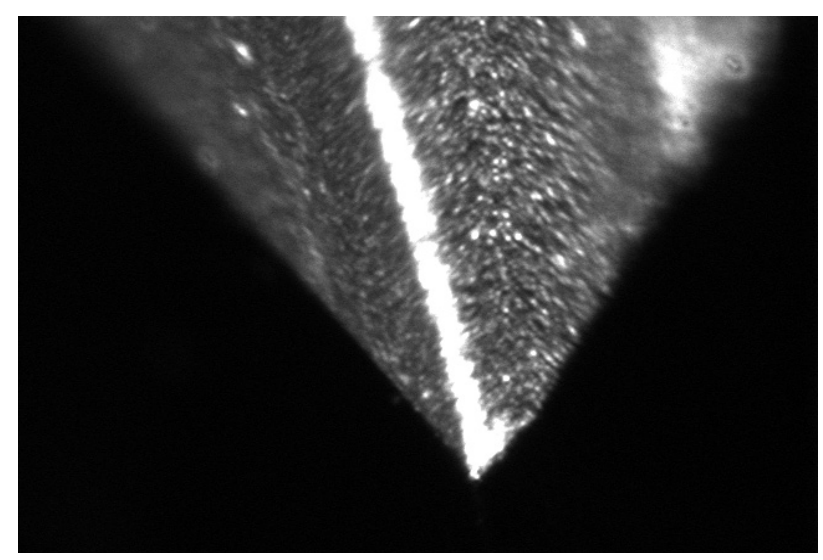

Before the contour extraction is performed, the raw image is preprocessed using the following workflow:

- removal of the fine-grained noise using the erosiondilation and median filtering

- image smoothing by the Gaussian-based filtering

- actual contour extraction based on Canny filter (edge detector) combined with the FloodFill algorithm

This procedure provides a few candidate contour curves (usually less than 5), from which only one is selected. The contour selection procedure is based on: its position in the image, size and shape (using a predefined tool shape). The selected contour is then corrected by using the artifacts removal procedure. The detected contour - the final result of this stage of algorithm - is presented in Fig. $3 b$.

\subsection{Conversion of the two-dimensional} coordinates into the three-dimensional ones and tool alignment in 3D space

2.3. Konverzija dvodimenzionalnoga koordinatnog sustava u trodimenzionalni i smještanje alata $u$ 3D prostor

The coordinate system, used during the analysis, is presented in Fig. 4.

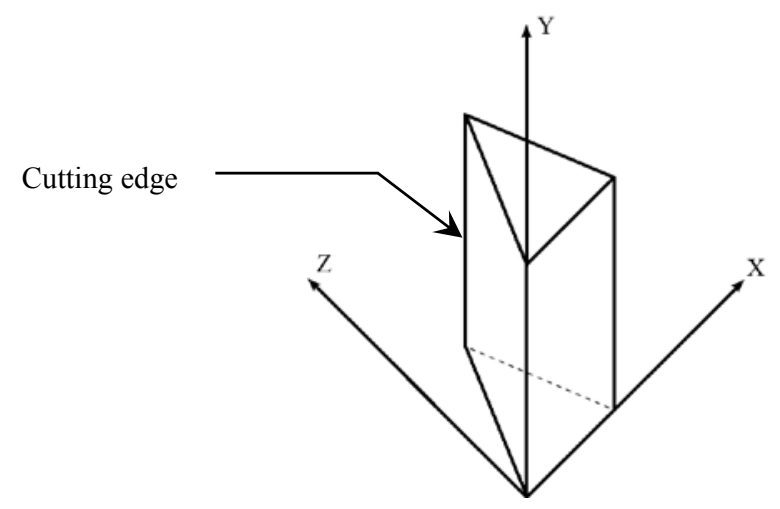

Figure 4 Coordinate system used for calculation Slika 4. Koordinatni sustav primijenjen za izračun

Figure 3 Image of illuminated tool: a) raw and b) with contour detected Slika 3. Slika osvijetljenog alata: a) izvorno, b) s označenim konturama 
The contours (one for every image, in 2D space), as the result of the previous stage, are converted into the point cloud description in the $3 \mathrm{D}$ space. The input data - contours - are defined in the $2 \mathrm{D}$ space related to the pixel coordinate system used in the images. This conversion is governed by the following rules:

$$
\text { p3D.x }=C_{1} \cdot p 2 D \cdot x \quad \text { p3D.y }=C_{1} \cdot p 2 D \cdot y+C_{2} \cdot i \quad p 3 D \cdot z=C_{1} \cdot p 2 D \cdot y \cdot \tan \alpha
$$

where:

$p 3 D$ coordinates of the point $(\mu \mathrm{m})$ from point cloud in 3D space

$p 2 D$ coordinates of the point (pixel) from the contour extracted from the image of the number num image

$C_{1}$ coefficient defining the scale of mapping $(\mu \mathrm{m} /$ pixel)

$C_{2}$ coefficient defining the Y-axis distance between consecutive scanned images analyzed in the previous stage of the algorithm $(\mu \mathrm{m})$

$i$ number of image

$\alpha \quad$ angle of the projector axis (in present setup $45^{\circ}$ )

If the alignment of the cutting edge is not perfect when compared to optical system during scanning, which may be caused by the tool itself or its fixing in the chuck, a virtual rotation of the point cloud is performed. This is done by detection of rake and clearance faces in the unused part of the tool. Using these two planes, the theoretical cutting edge is determined and the whole model is aligned to make the edge perpendicular to XZ plane.

\subsection{Calculation (in 3D space) of the missing points of the model, based on modified Shepard algorithm and final image post-} processing

2.4. Izračun (u 3D prostoru) točaka modela koje nedostaju na temelju Shepardova algoritma i konačno procesuiranje slike

The process of defining the final model of the scanned tool usually requires more data than is contained in the point cloud defined in $3 \mathrm{D}$ space. The missing points in the cloud are determined with help of the modified Shepard's method - the multivariate interpolation method for the scattered, irregular set of points. This method, in order to compute the parameters of the missing point, uses only the nearest neighbors within the R-sphere of this point instead of using the full data set. The modified Shepard's method requires an efficient spatial search data structure. In the present algorithm the kd-tree structure has been implemented. In the algorithm, the FLANN library (available under the BSD license) has been used for the implementation of the kd-tree structure.

The numerical experiments showed that the final model of the scanned tool, based on the supplemented point cloud, exhibits numerous artifacts, whose origin lies amongst others in the interpolation procedure. In order to minimize the number of artifacts and to weaken their intensity, the smoothing procedure is applied as the last step of the algorithm. This procedure is based on the set of Gaussian filters.

After the surface model of the tooth tip is created, it can be visualized using any $3 \mathrm{D}$ data analyzing software. Examples of the obtained models of tool's cutting edges visualized with Gwyddion software are shown in Figure 5.

a)

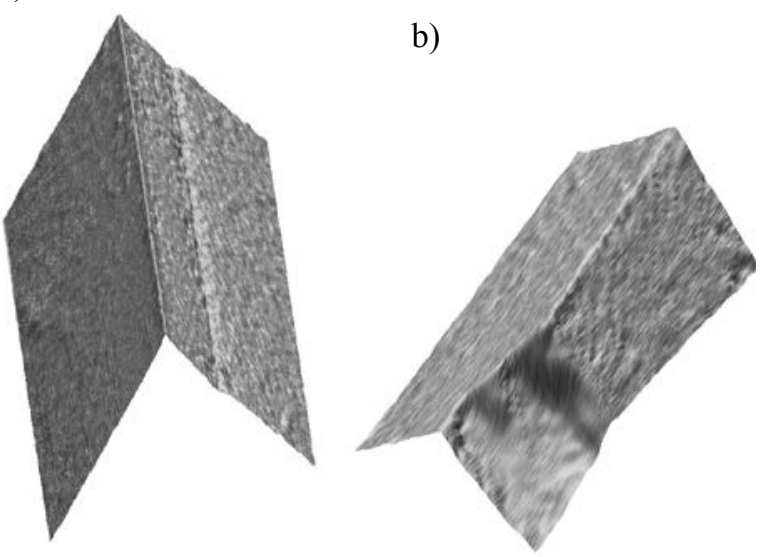

Figure 5 Surface models of diamond (PCD) cutting edges acquired with ToolScan: a) sharp insert on carbide base, b) catastrophic wear of tool (crushed)

Slika 5. Modeli površine dijamantnih (PCD) reznih oštrica snimljenih ToolScanom: a) oštar umetak na bazi karbida, b) katastrofalno trošenje alata (lom)

With these models, it is also possible to analyze the wear parameters. As mentioned above, most of widely used parameters intended to describe the tool wear are based on two dimensional data i.e. profiles of tool wedges. It is also possible to achieve such a profile from 3D model obtained by scanning. The digital nature of data facilitates the calculation and measurement of any tool wear parameter: cutting edge recession on the clearance and rake face, radius of rounding, nose width or even the volume of material removed from the tool (difference between sharp and worn wedge). Additionally, it is feasible to evaluate the volume of tooth tip loss along the cutting edge during scanning, assuming that profiles are extracted by sectioning the 3D surface with the planes perpendicular to the theoretical cutting edge.

\section{RESULTS AND DISCUSSION} 3. REZULTATI I RASPRAVA

A new hardware-software system ToolScan for 3D scanning of tool tip micro geometry was constructed within the framework of this project. The instrument 
possesses a great potential for tool wear inspection. However, it was crucial to confirm its functionality and accuracy. In order to verify ToolScan abilities, a comparative investigation was performed on cutting edges of changeable tool insert. One of its parts was used to machine 120 meters of MDF board cutting, the other - unused part was considered sharp. The zone containing both used and unused cutting edges (as well as transition between them) were scanned with two 3D methods: the shadow triangulation used in ToolScan and reference stereoscopic ESEM method, being at the moment one of the most precise tool inspection methods. For this work an ESEM XL 30 from FEI was used for the SEM-images with commercial software MeX® from Alicona Imaging $\mathrm{GmbH}$ for stereography.

To demonstrate the shadow scanner performance and accuracy, the surface models (3D maps) generated by both methods are presented in Figure 6 .

a)

b)
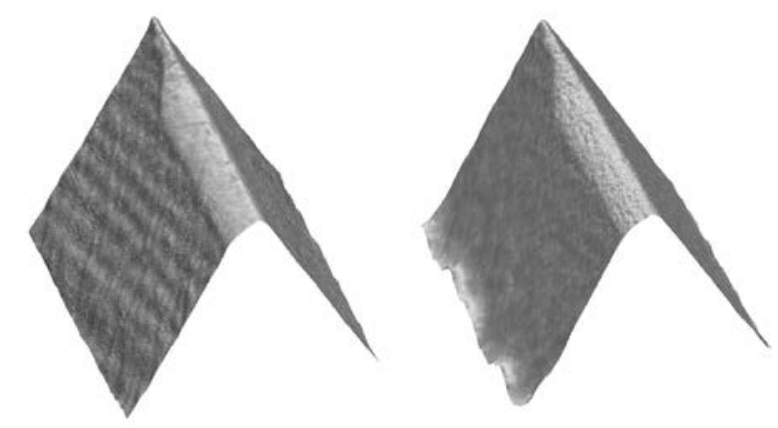

Figure 6 Surface models of sharp-to-blunt transition (c.a. $1 \mathrm{~mm} \times 1 \mathrm{~mm} \times 1 \mathrm{~mm}$ ) of the investigated tool after $120 \mathrm{~m}$ of cutting: a) performed by ToolScan, b) performed by reference ESEM method

Slika 6. Modeli promjene površine alata od oštre do tupe (oko $1 \mathrm{~mm} \times 1 \mathrm{~mm} \times 1 \mathrm{~mm}$ ) nakon rezanja $120 \mathrm{~m} \mathrm{u}$ duljinu: a) dobiven uz pomoć ToolScana, b) dobiven ESEM metodom

Next, they were sectioned with a plane perpendicular to theoretical cutting edge at the same position for both models. In this way two comparable profiles were found for worn zone and two for sharp zone, showing the rounding at the corresponding position of the edge (Fig. 7). Additionally, longitudinal profiles of the tool were acquired at the angle bisector plane, indicating the wear along the cutting edge (Fig. 8).

Figure 7 shows that both methods provide very comparable results. It should be noticed, though, that for ToolScan method some artifacts occur in the defocused zone of the images. In the focused zone small, bright particles are recognized as they are, but when moved into defocused zone, meaning fortunately that they are away from the interesting tool tip zone, they become no brighter but much bigger. When acquiring tool profile from images containing such a problem, the artifacts visible in Figure $7 \mathrm{~b}$ show up. For sharp tool, it is feasible to fit the circle to the tool tip $(R=10$ $\mu \mathrm{m})$, however the shape of worn insert tip does not al- a)

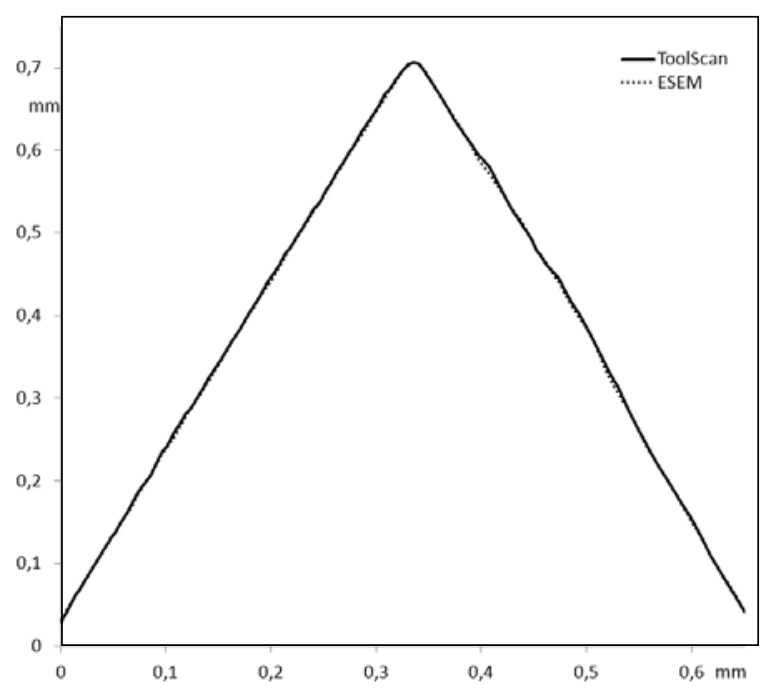

b)

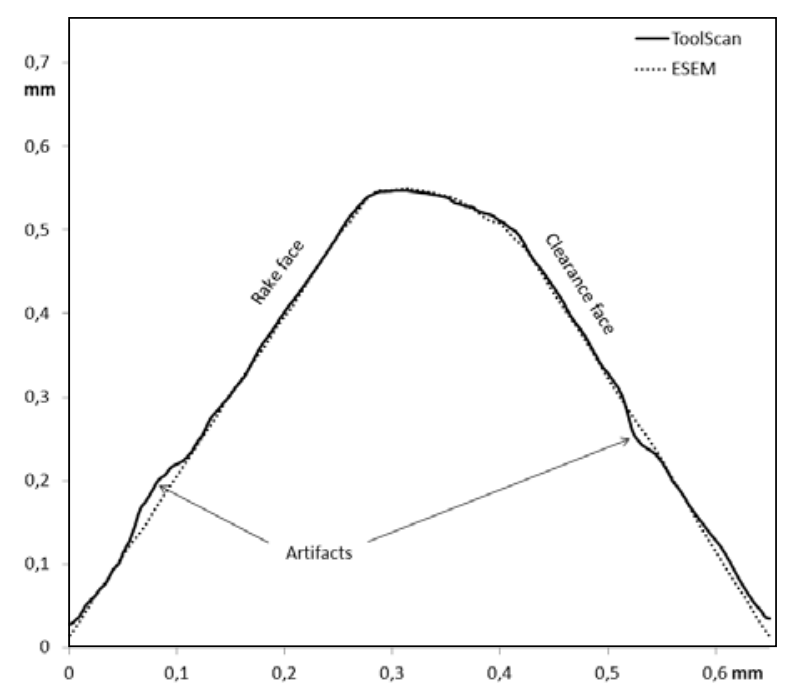

low to do it properly. This approach seems to have low reliability as a tool wear indicator in the present case. Figure 7 The carbide cutting edge rounding of: a) unused part of tool (tip radius $R=10 \mu \mathrm{m}$ ), b) $120 \mathrm{~m}$ of MDF cutting Slika 7. Zaobljenje karbidne rezne oštrice: a) neupotrijebljena oštrica (radijus zaobljenja $R=10 \mu \mathrm{m}$ ), b) nakon piljenja MDF ploče duljine $120 \mathrm{~m}$

Figure 8 shows that both methods recorded the transition of sharp-to-blunt zones, however, the profiles are not identical. Curves acquired with ToolScan are relatively "smoother". This is because the lightshadow border used in ToolScan is not perfectly sharp and therefore it works as a smoothing filter.

Even if the edge recession of $\sim 80 \mu \mathrm{m}$ was equal for both methods, the difference between profiles of both methods at the sharp-to-blunt transition zone would be visible. It might be explained by the fact that the optical properties of the scanned material significantly affect the accuracy of scanning. The light reflected from the slope area (passing from sharp to blunt) brightens the cutting edge and seemingly moves the shadow border higher compared to the situation when the measured surface is not polished. The estimation error is in this case at the level of $\sim 10 \mu \mathrm{m}$. 
Longitude position at the cutting edge $(\mathrm{mm})$

uzdužna pozicija na reznoj oštrici $(\mathrm{mm})$

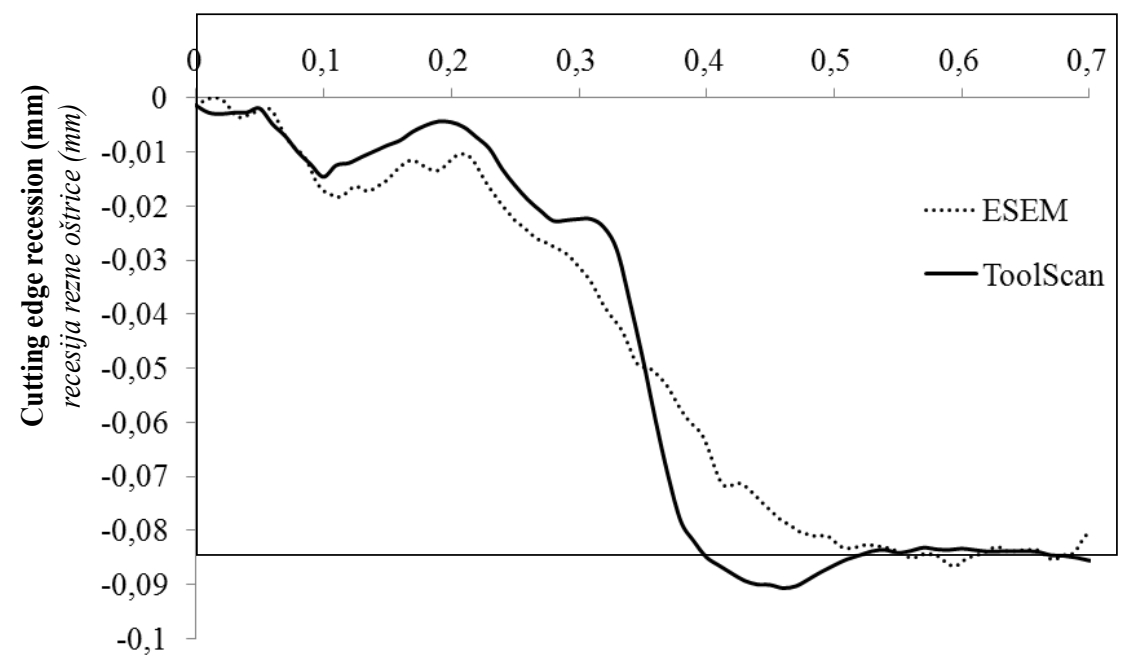

Figure 8 Longitude profile of cutting edge after $120 \mathrm{~m}$ of MDF cutting

Slika 8. Uzdužni profil rezne oštrice nakon duljine piljenja MDF ploče $120 \mathrm{~m}$

\section{CONCLUSIONS}

\section{ZAKLJUČAK}

A new method (both hardware and software) for three dimensional scanning of cutting tools micro-geometry has been developed within the framework of this project. It has shown a great potential in tool wear investigation, resulting in a 3D surface model of the investigated tool with micrometric accuracy comparable to the stereoscopic ESEM method. It is a fully nondestructive method, which allows multiple, fast, intermediate scanning e.g. during the determination of tool wear curve.

Although the shadow scanner performance encourages additional tests, it must be mentioned that, due to the optical nature of measurement, it is sensitive to the change of reflective properties of scanned materials. Moreover, it requires careful cleaning of tools and removing dust particles in order to avoid dirt artifacts. It is possible to adjust scanning parameters to the given tool material, but automating this procedure is not easy.

\section{Acknowledgement - Zahvala}

This work has been financed by the Polish Ministry of Science and Higher Education as an international non co-financed project (decision No. 542/N-Wlochy/2009/0). Special thanks are given to Mr. Roch Palubicki for his post-project private sponsorship. The authors wish to thank all helpful people involved in the realization of this project, especially: Ryszard Guzenda, Grzegorz Pinkowski, Wieslaw Rogowicz, Malgorzata Wojnowska (Poznan University of
Life Sciences, Poland) Piotr Sawosz and Piotr Beer (Warsaw University of Life Sciences, Poland).

Part of this work has been conducted within the framework of the project SWORFISH (team 2009 incoming (CALL 2) and Trentino - PCOFUNDGA-2008-226070) co-financed by Provincia Autonoma di Trento.

\section{REFERENCES}

5. LITERATURA

1. Aknouche, H.; Outahyon, A.; Nouveau, C.; Marchal, R.; Zerizer, A.; Butaud, J. C., 2009: Tool wear effect on cutting forces: in routing process of Aleppo Pine wood, Journal of Materials Processing Technology 209: 2918-2922. http://dx.doi.org/10.1016/j.jmatprotec.2008.06. 062

2. Bonamini, G.; Collet, R.; Del Taglia, A.; Fibbi, F.; Goli, G.; Remorini, R.; Uzielli, L., 1999: Equipement and test method for measuring cutting forces and wear of cutting edges in saw teeth for wood, improved with new HVOF coatings, Proceedings of the 14th International Wood Machining Seminar, September 12-19, p. 453-461.

3. Durazo-Cardenas, I.; Shore, P.; Luoa, X.; Jacklin, T.; Impey, S. A.; Coxc, A., 2007: 3D characterisation of tool wear whilst diamond turning silicon, Wear 262: 340-349. http://dx.doi.org/10.1016/j.wear.2006.05.022

4. Fuchs, I.; Endler, I.; Peter, M., 2005: High performance of hard metal tools for woodworking by gas boronizing, Proceedings of the 17th International Wood Machining Seminar, Rosenheim, Germany September 26-28, 542550 .

5. Ishida, K.; Tsutsumoto, T.; Banshoya, K., 2005: Cutting performance of Edge-sharpened Thick Diamond-film Brazed Milling Tools, Proceedings of the 17th International Wood Machining Seminar, Rosenheim, Germany September 26-28, 550-560.

6. Klamecki, B. E., 1979: A Review of Wood Cutting Tool Wear Literature, Holz als Roh- und Werkstoff 37: 265276. http://dx.doi.org/10.1007/BF02607429

7. Kapcia, J.; Orlowski, K. A.; Wasielewski, R., 2010: Mechatronic system for automatic inspection of circular saw teeth. In: Mechatronic Systems and Materials: Mechatronic Systems and Robotics. Book Series: Solid 
State Phenomena 164: 73-78. http://dx.doi.org/10.4028/ www.scientific.net/SSP.164.73

8. Kowaluk, G.; Szymanski, W.; Palubicki, B.; Beer, P., 2009: Examination of to ols of different materials edge geometry for MDF milling, Eur. J. Wood Prod. 67: 173176. http://dx.doi.org/10.1007/s00107-008-0302-0

9. Lemaster, R. L.; Lu, L.; Jackson, S., 2000a: The use of process monitoring techniques on a $\mathrm{CNC}$ wood router. Part 1. Sensor selection. Forest Products Journal 50 (7/8): 31-38.

10. Lemaster, R. L.; Lu, L.; Jackson, S., 2000b: The use of process monitoring techniques on a CNC wood router. Part 2. Use of a vibration accelerometer to monitor tool wear and workpiece quality, Forest Product Journal 50 (9): 59-64.

11. Lemaster, R.; Tee, L., 1985: Monitoring tool wear during wood machining with acoustic emission. Wear 101: 273282. http://dx.doi.org/10.1016/0043-1648(85)90081-X

12. McKenzie, W. M.; Karpovich, H., 1975: Wear and blunting of the tool corner in cutting a wood-based material, Wood Sci Technol 9: 59-73. http://dx.doi.org/10.1007/ BF00351915

13. Miklaszewski, S.; Zurek, M.; Beer, P.; Sokolowska, A., 2000: Micromechanism of polycrystalline cementem diamond tool wear Turing milling of wod based materials, Diamond and related materials 9: 1125-1128. http:// dx.doi.org/10.1016/S0925-9635(99)00370-2

14. Niranjan Prasad, K.; Ramamoorthy, B., 2001: Tool wear evaluation by stereo vision and prediction by artificial neural network, Journal of Materials Processing Technology 112: 43-52. http://dx.doi.org/10.1016/S09240136(00)00896-7

15. Nordström, J.; Bergström, J., 2001: Wear testing of saw teeth in timber cutting, Wear 250: 19-27. http://dx.doi. org/10.1016/S0043-1648(01)00625-1

16. Novacek, E.; Novak, V., 2006: Possibilities of measuring tool-wear (in Slovak), Medzinárodná vedecká konferencia 10 Conf. Trendy lesnickej, drevarskej a environmmentalej techniky, Zvolen, Slovak Republic, 5 - 7 september 2006: 330-336.

17. Ohuchi, T.; Kameyama, J.; Murase, Y., 2003: Development of automatic measurement system for both wear and cutting edge profile of router bit, Proceedings of the 16th International Wood Machining Seminar, Matsue, Japan, August 24 -27.

18. Okai, R.; Tanaka, C.; Iwasaki, Y., 2006: Influence of mechanical properties and mineral salts in wood species on tool wear of high-speed steels and stellite-tipped tools Consideration of tool wear of the newly developed tip- inserted band saw, Holz als Roh- und Werkstoff 64: 4552. http://dx.doi.org/10.1007/s00107-005-0015-6

19. Paris, H.; Peigne, G., 2007: Influence of the cutting tool geometrical defect on the dynamic behavior of machining, Int J Interact Des Manuf 1: 41-49. http://dx.doi. org/10.1007/s12008-007-0005-5

20. Porankiewicz, B.; Sandak, J.; Tanaka, C., 2005: Factor influencing steel tool wear when milling Wood, Wood Sci Technol 39: 225-234. http://dx.doi.org/10.1007/ s00226-004-0282-0

21. Ramasamy, G.; Ratnasingam, J., 2010: A review of Cemented Tungsten Carbide tool wear during wood cutting process, Journal of Applied Sciences 10 (22): 2799-2804. http://dx.doi.org/10.3923/jas.2010.2799.2804

22. Sandak, J., 2007: Optical triangulation in wood surface roughness measurement, Proceedings of the 18th International Wood Machining Seminar, Vancouver, Vol.1, pp. 275-284.

23. Sandak, J.; Pałubicki, B.; Kowaluk, G., 2011: Measurement Of The Cutting Tool Edge Recession With Optical Methods; Proceedings of the 20th International Wood Machining Seminar, 7.-10. 6. 2011, Skellefteå, Sweden: 97-106.

24. Sandak, J.; Tanaka, Ch., 2005: Evaluation of Surface Smoothness Using a Light-Sectioning Shadow Scanner, Journal of Wood Science, 51 (3): 270-273. http://dx.doi. org/10.1007/s10086-004-0637-z

25. Sheikh-Ahmad, J. Y.; Bailey, J. A., 1999: The wear characterisctics of some cemented tungsten carbides in machining particleboard, Wear 225-229: 256-266. http:// dx.doi.org/10.1007/BF00538952

26. Sheikh-Ahmad, J. Y.; Stewart, J. S.; Feld, H., 2003: Failure characteristic of diamond coated carbides in machining wood-based composites, Wear 255: 1433-1437. http://dx.doi.org/10.1016/S0043-1648(03)00179-0

27. Sokolowski, W.; Gogolewski, P., 1999: Temperature of machined surface as a value for tool condition monitoring during woodproducts milling, Proceedings of the 14th International Wood Machining Seminar, Paris-Epinal-Cluny, France.

28. Tanaka, C.; Nakao, T.; Nishino, Y.; Hamaguchi, T.; Takahashi, A., 1992: Detection of wear degree of cutting tool by acoustic emission signal. Mokuzai Gakkaishi 38 (9): 841-846.

29. Wasielewski, R.; Orlowski, K. A., 2005: Inspection of circular saw teeth quality. Wood Research, 50 (4): 43-50.

\section{Corresponding address:}

Assistant professor BARTOSZ PALUBICKI, Ph.D. Department of Woodworking Machinery and Basis of Machines Construction

Poznan University of Life Sciences

ul. Wojska Polskiego 38/42

60-627 Poznan, POLAND

e-mail: bpalubic@up.poznan.pl 